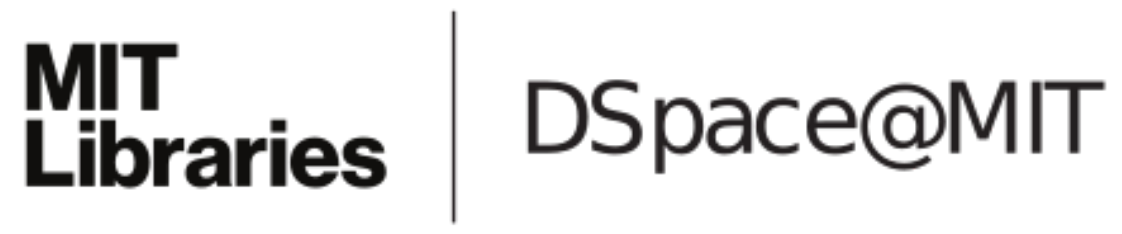

\author{
MIT Open Access Articles
}

Biophysical Examination of the Calcium-Modulated Nickel-Binding Properties of Human Calprotectin Reveals Conformational Change in the EF-Hand Domains and His3Asp Site

The MIT Faculty has made this article openly available. Please share how this access benefits you. Your story matters.

Citation: Nakashige, Toshiki G. et al. "Biophysical Examination of the Calcium-Modulated NickelBinding Properties of Human Calprotectin Reveals Conformational Change in the EF-Hand Domains and His3Asp Site." Biochemistry 57, 28 (June 2018): 4155-4164 ( 2018 American Chemical Society

As Published: http://dx.doi.org/10.1021/acs.biochem.8b00415

Publisher: American Chemical Society (ACS)

Persistent URL: https://hdl.handle.net/1721.1/126135

Version: Author's final manuscript: final author's manuscript post peer review, without publisher's formatting or copy editing

Terms of Use: Article is made available in accordance with the publisher's policy and may be subject to US copyright law. Please refer to the publisher's site for terms of use. 


\title{
Biophysical Examination of the Calcium-Modulated Nickel- Binding Properties of Human Calprotectin Reveals Conformational Change in the EF-Hand Domains and $\mathrm{His}_{3} \mathrm{Asp}$ Site
}

\author{
Toshiki G. Nakashige ${ }^{1}$, Sarah E. J. Bowman ${ }^{1,2,3,4}$, Emily M. Zygiel ${ }^{1}$, Catherine L.

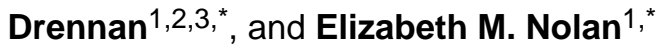 \\ ${ }^{1}$ Department of Chemistry, Massachusetts Institute of Technology, Cambridge, MA 02139, USA \\ ${ }^{2}$ Department of Biology, Massachusetts Institute of Technology, Cambridge, MA 02139, USA \\ ${ }^{3}$ Howard Hughes Medical Institute, Massachusetts Institute of Technology, Cambridge, MA 02139, \\ USA
}

\begin{abstract}
Calprotectin (CP, S100A8/S100A9 oligomer, MRP-8/MRP-14 oligomer) is a host-defense protein that sequesters nutrient transition metals from microbes. Each S100A8/S100A9 heterodimer contains four EF-hand domains and two transition-metal-binding sites. We investigate the effect of $\mathrm{Ca}$ (II) ions on the structure and $\mathrm{Ni}$ (II)-binding properties of human $\mathrm{CP}$. By employing energy dispersive X-ray (EDX) spectroscopy, we evaluate the metal content of Ni(II)-bound CP-Ser (oligomer of S100A8(C42S) and S100A9(C3S)) crystals obtained in the absence and presence of $\mathrm{Ca}(\mathrm{II})$. We present a 2.1 - $\AA$ resolution crystal structure of Ni(II)-bound CP-Ser and compare this structure to a reported $\mathrm{Ni}(\mathrm{II})$ - and $\mathrm{Ca}$ (II)-bound CP-Ser structure (Nakashige, T. G. et al. J. Am. Chem. Soc. 2017, 139, 8828-8836). This analysis reveals conformational changes associated with $\mathrm{Ca}$ (II) coordination to the EF-hands of S100A9, and that $\mathrm{Ca}$ (II) binding affects the coordination number and geometry of the $\mathrm{Ni}(\mathrm{II})$ ion bound to the $\mathrm{His}_{3} \mathrm{Asp}$ site. In contrast, negligible differences are observed for the $\mathrm{Ni}(\mathrm{II})-\mathrm{His}_{6}$ site in the absence and presence of $\mathrm{Ca}(\mathrm{II})$. Biochemical studies show that, whereas the $\mathrm{His}_{6}$ site has a thermodynamic preference for $\mathrm{Ni}$ (II) over $\mathrm{Zn}(\mathrm{II})$, the His ${ }_{3} \mathrm{Asp}$ site selects for $\mathrm{Zn}$ (II) over Ni(II), and relatively rapid metal exchange occurs at this site. These observations inform the working model for how CP withholds nutrient metals in the extracellular space.
\end{abstract}

\section{Graphical Abstract}

*Corresponding authors: cdrennan@mit.edu and lnolan@mit.edu Phone: 617-452-2495.

${ }^{4}$ Current address: Hauptman-Woodward Medical Research Institute, Buffalo, NY 14203, USA

Supporting Information

Complete experimental methods, Tables S1-S8, Figures S1-S7, and supporting references. This material is available free of charge via the Internet at http://pubs.acs.org. 


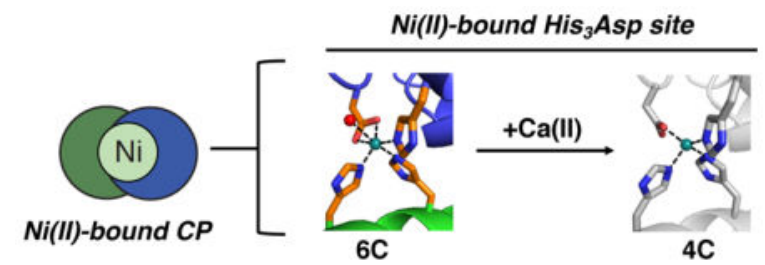

\section{Introduction}

Calprotectin (CP, S100A8/S100A9 oligomer, MRP-8/MRP-14 oligomer) is an abundant metal-chelating protein that is released at sites of microbial infection as part of the host innate immune response. ${ }^{1-5} \mathrm{CP}$ exhibits broad-spectrum antimicrobial activity attributed to its ability to sequester essential metal nutrients from invading pathogens. ${ }^{1,4,6,7}$ Human CP coordinates divalent first-row transition metals, including $\mathrm{Mn}(\mathrm{II}),{ }^{8-13} \mathrm{Fe}(\mathrm{II}),{ }^{14-16} \mathrm{Ni}(\mathrm{II}),{ }^{17}$ $\mathrm{Cu}(\mathrm{II}),{ }^{18}$ and $\mathrm{Zn}(\mathrm{II}),{ }^{8,19,20}$ with sufficiently high affinity to prevent microbial acquisition of these nutrients.

$\mathrm{CP}$ is the heterooligomer of the S100 proteins S100A8 (a subunit) and S100A9 ( $\beta$ subunit). 21,22 The CP heterodimer exhibits six different sites for coordinating metal ions. Each subunit has two $\mathrm{Ca}$ (II)-binding EF-hand domains, a C-terminal canonical ("calmodulinlike") site and an N-terminal non-canonical site. ${ }^{23-25}$ Apo CP exists as the $\alpha \beta$ heterodimer, and $\mathrm{Ca}(\mathrm{II})$ coordination at the EF-hand domains causes two heterodimers to self-associate and form the $\alpha_{2} \beta_{2}$ heterotetramer. ${ }^{22,23,26,27} \mathrm{Ca}$ (II) binding also increases the transitionmetal affinities of $\mathrm{CP},{ }^{9,14,19}$ enhances its antimicrobial activity, ${ }^{2,4,19}$ and affords greater proteolytic stability. ${ }^{28}$ The two transition-metal sites are present at the interface between the S100A8 and S100A9 subunits. The His 3 Asp motif (site 1) is composed of (A8)His83, (A8)His87, (A9)His20, and (A9)Asp30. This site coordinates Zn(II) with high affinity such that it can sequester $\mathrm{Zn}$ (II) from microbes. ${ }^{14,20}$ It also coordinates $\mathrm{Mn}(\mathrm{II}),{ }^{9} \mathrm{Fe}(\mathrm{II}),{ }^{15}$ and $\mathrm{Ni}(\mathrm{II}) .{ }^{17}$ The His 6 site (site 2) is composed of (A8)His17, (A8)His27, (A9)His91, (A9)His95, (A9)His103, and (A9)His105. This site is functionally versatile because it has the capacity to sequester multiple first-row transition metal ions from microbes. Site 2 coordinates $\mathrm{Mn}(\mathrm{II}),{ }^{10-12} \mathrm{Fe}(\mathrm{II}),{ }^{14,15} \mathrm{Ni}(\mathrm{II}),{ }^{17}$ and $\mathrm{Zn}(\mathrm{III}){ }^{20}$ in an octahedral environment with relative affinities that agree with the Irving-Williams series $\left(K_{\mathrm{d}, \mathrm{Mn}}>K_{\mathrm{d}, \mathrm{Fe}}>K_{\mathrm{d}, \mathrm{Zn}}>\right.$ $\left.K_{\mathrm{d}, \mathrm{Ni}}\right) \cdot{ }^{9,14,17,29}$

Despite multiple reports demonstrating that $\mathrm{Ca}(\mathrm{II})$ affects the structural and functional properties of $\mathrm{CP}$, we currently have a limited molecular understanding of these processes. For proteins that exhibit $\mathrm{Ca}(\mathrm{II})$-dependent conformational changes such as calmodulin, $\mathrm{X}$ ray crystallography has been instrumental in understanding structural flexibility in the absence and presence of $\mathrm{Ca}(\mathrm{II}){ }^{30}$ This technique has also yielded four structures of $\mathrm{CP}$ to date: one structure of $\mathrm{Ca}$ (II)-bound CP (PDB: 1XK4), ${ }^{23}$ two structures of $\mathrm{Mn}$ (II)- and $\mathrm{Ca}(\mathrm{II})$-bound CP (PDB: 4GGF, 4XJK), ${ }^{10,12}$ and a structure of Ni(II)- and $\mathrm{Ca}(\mathrm{II})$-bound $\mathrm{CP}$ (PDB: 5W1F). ${ }^{17}$ These studies have provided invaluable insights into the coordination chemistry of this host-defense protein and a guide for many studies. Nevertheless, all reported crystal structures of $\mathrm{CP}$ are of $\mathrm{Ca}$ (II)-bound forms and thus provide no insight into 
$\mathrm{Ca}(\mathrm{II})$-free forms of the protein as well as how $\mathrm{Ca}(\mathrm{II})$ binding affects protein structure, the transition metal sites, and ultimately function.

In this work, we report crystallographic and solution studies of $\mathrm{Ni}$ (II) binding to human $\mathrm{CP}$ in the absence and presence of $\mathrm{Ca}$ (II). We first employ a single-crystal elemental analysis synchrotron technique to evaluate the metal content of X-ray quality crystals of CP obtained in the presence of $\mathrm{Ni}$ (II) ions only or both $\mathrm{Ni}$ (II) and $\mathrm{Ca}$ (II) ions. Moreover, we present an $\mathrm{X}$-ray structure of $\mathrm{Ni}(\mathrm{II})$-bound $\mathrm{CP}$ and compare this structure to a reported $\mathrm{Ni}(\mathrm{II})$ - and $\mathrm{Ca}(\mathrm{II})$-bound $\mathrm{CP}$ structure. ${ }^{17}$ This analysis highlights conformational changes that occur at the EF-hand domains of S100A9 with $\mathrm{Ca}(\mathrm{II})$ binding, as well as a change in the $\mathrm{Ni}(\mathrm{II})$

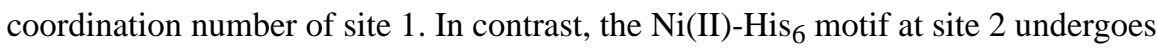
negligible structural change as a result of $\mathrm{Ca}(\mathrm{II})$ binding. Although the presence of $\mathrm{Ca}(\mathrm{II})$ ions affect the $\mathrm{Ni}$ (II) coordination spheres at site 1 and site 2 differently, solution studies show that $\mathrm{Ca}$ (II) ions enhance the $\mathrm{Ni}$ (II) affinities of both sites. Lastly, a comparison of metal substitution at the $\mathrm{His}_{3} \mathrm{Asp}$ and $\mathrm{His}_{6}$ sites shows markedly different behavior. Whereas the $\mathrm{His}_{6}$ site entraps and retains a bound metal ion, the His ${ }_{3} \mathrm{Asp}$ site rapidly selects for $\mathrm{Zn}(\mathrm{II})$. Taken together, this work informs how $\mathrm{Ca}(\mathrm{II})$ ions modulate transition metal binding by $\mathrm{CP}$ and, in particular, provides new insight into metal chelation by the His ${ }_{3} \mathrm{Asp}$ motif.

\section{Experimental Methods}

Complete experimental methods are provided as Supporting Information.

\section{Results}

\section{Metal Analysis of Single Crystals by Energy Dispersive X-ray Spectroscopy}

Previous crystallographic studies employed CP-Ser, ${ }^{10,12,17,23}$ the heterooligomer of S100A8(C42S) and S100A9(C3S) (Table S1), to avoid disulfide bond formation, and we use this variant in the current study. These two Cys residues are not implicated in transitionmetal binding, and CP-Ser exhibits comparable metal-binding properites and antimicrobial activity to native CP. ${ }^{19}$ Purified CP-Ser is purified without use of an affinity tag, and following column chromatography, the protein is dialyzed against Chelex resin to reduce metal contamination. ${ }^{19}$ We obtained crystals of Ni(II)-bound CP-Ser employing the sittingdrop vapor diffusion method, using a 1:1 molar ratio of $\mathrm{Ni}$ (II) and CP-Ser heterodimer. The precipitant solution of $200 \mathrm{mM} \mathrm{Li}_{2} \mathrm{SO}_{4}, 100 \mathrm{mM}$ Tris, 20\% (v/v) PEG 3350, pH 8.0 did not include added $\mathrm{Ca}$ (II) ions. Because $\mathrm{Ca}$ (II) ions are a common contaminant, we sought to compare the $\mathrm{Ca}$ (II)-free and $\mathrm{Ca}$ (II)-bound forms of $\mathrm{Ni}$ (II)-bound CP-Ser and employed energy dispersive X-ray (EDX) spectroscopy to evaluate the levels of calcium and other metals in the crystals (Figure 1). Based on an established method to evaluate the elemental composition of materials, ${ }^{31}$ this technique can be utilized to analyze the $\mathrm{X}$-ray fluorescence of elements present in single-crystal samples and can be used in tandem with collecting diffraction data on the synchrotron beamline. ${ }^{32} \mathrm{X}$-rays at a fixed incident energy are used to excite elements that emit photons corresponding their K-edge energies, with Compton backscattering observed near the incident energy. Fluorescence counts of various elements are detected, and emission spectra are calibrated to a standard containing $\mathrm{Sm}, \mathrm{Ni}, \mathrm{Zn}, \mathrm{Br}$, and Sr. Crystals were analyzed on 100- $\mu \mathrm{m}$ loops, and measurements for the sample (X-rays 
positioned on crystal, red lines in Figure 1) and a blank (X-rays positioned on an empty space of the loop, black lines in Figure 1) were taken at $0.9792 \AA$ incident energy. Data acquisition times were the same for each pair of sample and blank.

Results from this single-crystal elemental analysis indicate that the crystal obtained in the absence of $\mathrm{Ca}$ (II) and later employed for X-ray diffraction (vide infra) contained negligible $\mathrm{Ca}\left(\mathrm{Ka}_{1} 3.69 \mathrm{keV}\right)$ compared to the blank (Figure 1A,1C). In contrast, the Ca content was notably higher for a crystal obtained under the same crystallization conditions that was subsequently soaked in $\mathrm{Ca}$ (II) (i.e., $\mathrm{Ni}(\mathrm{II})$ - and $\mathrm{Ca}(\mathrm{II})$-bound $\mathrm{CP}$-Ser described previously ${ }^{17}$ ) (Figure 1B,1C). We also employed EDX line scans to evaluate relative concentrations of transition metals, including $\mathrm{Ni}$ and contaminants that could be present in the crystallization conditions. Both crystals exhibited high concentrations of $\mathrm{Ni}\left(\mathrm{Ka}_{1} 7.48 \mathrm{keV}, \mathrm{K} \beta_{1} 8.26 \mathrm{keV}\right)$. In addition, contaminating levels of $\mathrm{Zn}\left(\mathrm{Ka}_{1} 8.64 \mathrm{keV}\right)$ and trace amounts of $\mathrm{Fe}\left(\mathrm{Ka}_{1} 6.40\right.$ $\mathrm{keV}$ ) were detected. Nevertheless, we expect that $\mathrm{Ni}$ will be in excess of any contaminating metal ions, and this elemental analysis in conjunction with our anomalous scattering data (vide infra) supports (i) that the $\mathrm{Ni}$ (II)-bound crystal is effectively $\mathrm{Ca}$ (II)-free and (ii) that $\mathrm{Ni}(\mathrm{II})$ ions can be unambiguously assigned to the transition-metal-binding sites.

\section{Crystal Structure of $\mathrm{Ni}(\mathrm{II})-$-bound $\mathrm{CP}-\mathrm{Ser}$ in the Absence of $\mathrm{Ca}$ (II)}

$\mathrm{X}$-ray diffraction data were collected on the $\mathrm{Ni}(\mathrm{II})$-containing crystal obtained in the absence of added $\mathrm{Ca}$ (II) that was analyzed by EDX spectroscopy, and a structure was solved to 2.1- $\AA$ resolution (Table S2) by employing the $\mathrm{Mn}(\mathrm{II})-, \mathrm{Ca}(\mathrm{II})-$, and $\mathrm{Na}(\mathrm{I})$-bound CP-Ser crystal structure (PDB: 4XJK) ${ }^{12}$ as the molecular replacement model. Ni(II)-bound CP-Ser crystallized as an $\alpha_{2} \beta_{2}$ heterotetramer (Figure $2 \mathrm{~A}$ ).

Electron density at the four transition-metal-binding sites of the tetramer was consistent with metals bound at one of the $\mathrm{His}_{3}$ Asp motifs and both $\mathrm{His}_{6}$ motifs of the tetramer (Figure 2B, Tables 1, S3-S6). To confirm the identity of the metals at these sites, anomalous scattering datasets were also collected at the $\mathrm{Ni}(1.4831 \AA)$ and Fe (1.7370 $\mathrm{\AA}) \mathrm{K}$-edges and processed to 2.3- and 2.6- $\AA$ resolution, respectively. Maps generated from these anomalous data support that all three metal ions are $\mathrm{Ni}(\mathrm{II})$. Anomalous signal is observed at the $\mathrm{Ni}$ peak (Figure 2B), and we assigned Ni(II) ions at 100\% occupancy at all three sites (Table 1). Thus, although the crystallization conditions contained only 1.0 equiv $\mathrm{Ni}(\mathrm{II})$ relative to the heterodimer, the crystallization yielded a 3:2 $\mathrm{Ni}$ (II) to $\mathrm{CP}$ heterotetramer ratio. This same ratio was observed in the structure of $\mathrm{Ni}$ (II)- and $\mathrm{Ca}$ (II)-bound $\mathrm{CP}-\mathrm{Ser}$ that contains $\mathrm{Ni}$ (II) ions bound to both $\mathrm{His}_{6}$ sites and one $\mathrm{His}_{3} \mathrm{Asp}$ site of the heterotetramer, suggesting that the metallation state of CP-Ser is not homogeneous under crystallization conditions and that the more fully metallated protein is preferentially crystallized. ${ }^{17}$

The EDX data (vide supra) show no Ca signal in Ni(II)-bound CP-Ser crystals and anomalous maps generated using data collected at the Fe K-edge (1.7370 $\AA$ ) also indicate a lack of $\mathrm{Ca}$ (II) ions (Figure S1). Because the Ca K-edge at $3.3582 \AA$ is inaccessible for data collection at most synchrotrons, $\mathrm{Ca}(\mathrm{II})$ scattering is often evaluated by using data collected at the Fe Kedge (1.7370 $)$. The Fe anomalous maps show density for the Ni(II) ions that are bound at sites 1 and 2, as expected, because Ni scatters anomalously at this wavelength. $\mathrm{Ca}$, if present in the sample, should display stronger anomalous scattering than $\mathrm{Ni}$ at the $\mathrm{Fe}$ 
$\mathrm{K}$-edge wavelength, but no anomalous density is present at the EF-hand domains (Figure $\mathrm{S} 1$ ), suggesting that $\mathrm{Ca}(\mathrm{II})$ is not bound. To determine if another atom is bound in these sites, the electron density was evaluated. Three of the eight EF-hands do not exhibit electron density, and we consider these sites to be metal-free (Table 1). The other five EF-hand domains exhibit electron density consistent with an atom present at these sites. Previous structures have been refined with $\mathrm{Na}(\mathrm{I})$ ions at select EF-hands, ${ }^{12,17}$ and our crystallization condition contained 1000-fold excess $\mathrm{Na}(\mathrm{I})(100 \mathrm{mM})$ compared to the concentration of CPSer $(100 \mu \mathrm{M})$. To evaluate if $\mathrm{Na}(\mathrm{I})$ ions provide a good fit in this structure, $\mathrm{Na}(\mathrm{I})$ was refined at 100\% occupancy in all five sites (Tables 1, S7). No positive or negative difference electron density appeared, indicating that $\mathrm{Na}(\mathrm{I})$ is consistent with the crystallographic data.

\section{Conformational Changes at the EF-hand Domains upon $\mathrm{Ca}$ (II) Coordination}

To examine the conformational changes that occur upon $\mathrm{Ca}$ (II) coordination, we compared the $\mathrm{Ni}(\mathrm{II})$-bound CP-Ser structures obtained in the absence and presence of $\mathrm{Ca}(\mathrm{II})$. We first examined the EF-hand domains of S100A9 that are adjacent to site 1 (Figure 3). Dimer 1 has no metal at the $\mathrm{His}_{3} \mathrm{Asp}$ motif (site 1) in both structures, and the $\mathrm{Ca}(\mathrm{II})$-free species (Figure 3A), in which both EF-hand domains are empty, exhibits several sidechain and loop rearrangements when compared to the $\mathrm{Ca}(\mathrm{II})$-bound structure (Figure 3B). In particular, the loop that contributes (A9)Asp30 has undergone a conformational rearrangement, resulting in substantially different positions for (A9)Leu26 and (A9)His28 and an altered conformation of the (A9)Asp30 residue that is pointing away from the three His residues of the His 3 Asp motif ((A9)His20, (A8)His83, (A8)His87 in Figure 3A). With the non-canonical site empty in the $\mathrm{Ca}(\mathrm{II})$-free structure, the side chain of (A8)His87 of the His 3 Asp motif has also moved toward the empty site, and (A9)His20 of the $\mathrm{His}_{3}$ Asp motif has moved down toward the position vacated by (A8)His87 (Figure 3A). The net result of these movements is that three of the four residues of the His 3 Asp motif are not arranged to bind a metal ion. Site 1 is also empty in the $\mathrm{Ca}$ (II)-bound structure (Figure 3B), but the side chains of all the residues of the $\mathrm{His}_{3}$ Asp motif are all much closer to their metal-binding orientations (compare Figure 3B to Figure 3D). In the $\mathrm{Ca}(\mathrm{II})$-bound structure, $\mathrm{Na}(\mathrm{I})$ occupies the non-canonical site, which further stabilizes the (A9)Asp30 loop and helps to maintain the positions of (A8)His87 and (A9)His20 in their metal-binding orientations (Figure 3B). Connectivity in dimer 1 between the canonical EF-hand with $\mathrm{Ca}$ (II) bound, the non-canonical site with $\mathrm{Na}$ (I) bound, and site 1 is apparent in the $\mathrm{Ca}$ (II)-bound structure (Figure 3B). In particular, residues of the S100A9 canonical EF-hand (i.e., Asp67, Asn69, Asp71, Gln73, and Glu78) adjust upon Ca(II) binding and Gln73 moves closer to the non-canonical site where it forms a hydrogen bond to a coordinating water of the bound $\mathrm{Na}(\mathrm{I})$ ion, the non-canonical site appears to be stabilized, and the resulting well-ordered non-canonical site appears to stabilize residues of the $\mathrm{His}_{3}$ Asp motif in metal-binding orientations (Figure 3B).

Although dimer 2 displays fewer conformational rearrangements between the $\mathrm{Ca}$ (II)-bound and $\mathrm{Ca}(\mathrm{II})$-free structures, the same general trends as described above are observed. Dimer 2 coordinates a $\mathrm{Ni}(\mathrm{II})$ ion in the $\mathrm{His}_{3}$ Asp motif (site 1) in both structures, and both structures have a metal ion, either $\mathrm{Na}$ (I) or $\mathrm{Ca}(\mathrm{II})$, in the non-canonical site (Figure 3C,D). As observed in dimer 1, ordering of EF-hand residues upon $\mathrm{Ca}$ (II) binding results in the formation of a hydrogen bond between (A9)Gln73 and a water molecule that is coordinated to the metal in 
the non-canonical site, and the non-canonical site is well-ordered and residues of the $\mathrm{His}_{3} \mathrm{Asp}$ motif are positioned to bind $\mathrm{Ni}(\mathrm{II})$ (Figure 3D). In the $\mathrm{Ca}(\mathrm{II})$-free structure, (A9)Gln73 does not hydrogen bond to the $\mathrm{Na}(\mathrm{I})$-coordinating water, and $\mathrm{Na}(\mathrm{I})$ has fewer protein ligands than are observed at this dimer 2 site when $\mathrm{Ca}$ (II) is bound. Namely, $\mathrm{Na}$ (I) has two sites occupied by water molecules in the $\mathrm{Ca}$ (II)-free structure whereas the $\mathrm{Ca}$ (II) ion at the non-canonical site is coordinated by (A9)Glu36 in a bidentate fashion. Importantly, neither Ni(II)-bound CP-Ser structure includes a CP heterodimer species with a $\mathrm{Ni}$ (II) ion at site 1 and without a metal ion at the S100A9 non-canonical EF-hand (i.e., site 1 is not occupied unless a metal is present at the non-canonical EF-hand), which suggests that cooperativity exists between these two sites. Lastly, although a $\mathrm{Ni}(\mathrm{II})$ ion is bound at site 1 of dimer 2 in the absence of $\mathrm{Ca}(\mathrm{II})$, the geometry and ligand identity is altered (vide infra).

\section{The Ni(II) Coordination Sphere at the $\mathrm{His}_{3}$ Asp Motif}

The conformational changes of the EF-hand domains adjacent to site 1 of dimer 2 result in a shift in the primary coordination sphere of $\mathrm{Ni}(\mathrm{II})$ at the $\mathrm{His}_{3} \mathrm{Asp}$ motif (Figure 4 and Supporting Video). The $\mathrm{Ca}$ (II)-free CP-Ser structure exhibits a six-coordinate $\mathrm{Ni}(\mathrm{II})$ center, where the bond distances and angles are consistent with a pseudooctahedral coordination environment (Tables S3, S4). In addition to the three His residues, a bidentate (A9)Asp30, and a solvent-derived water molecule complete this site. When $\mathrm{Ca}$ (II) binds at the adjacent S100A8 EF-hand domains, Asp30 rotates $\approx 45^{\circ}$, positioning one of the oxygen ligands (O反2) $\approx 0.5 \AA$ away from the $\mathrm{Ni}(\mathrm{II})$ ion, thereby forming a tetrahedral $\mathrm{Ni}(\mathrm{II})$ center with a monodentate (A9)Asp30 and no coordinating water molecule. Thus, although $\mathrm{Ni}$ (II) can bind to site 1 without $\mathrm{Ca}$ (II) being present, only the $\mathrm{Ca}$ (II)-bound structure displays the tetrahedral His ${ }_{3}$ Asp arrangement that is associated with higher affinity metal binding.

\section{The Ni(II) Coordination Sphere at the $\mathrm{His}_{6}$ Motif}

Site 2 is adjacent to the EF-hand domains of S100A8 (Figure S2). However, structural alignments show that site 2 does not exhibit marked conformational changes upon $\mathrm{Ca}(\mathrm{II})$ binding to the S100A8 EF-hand domains (Figures 5, S2). In the Ca(II)-free structure, $\mathrm{Na}$ (I) ions are present at both $\mathrm{EF}-$ hand domains, and in the $\mathrm{Ca}$ (II)-bound structure, $\mathrm{Ca}$ (II) replaces $\mathrm{Na}$ (I) at the canonical EF-hand. Regardless of identity, the primary coordination sphere of the metal bound to the S100A8 EF-hand domain is the same. Moreover, the Ni(II)-bound $\mathrm{His}_{6}$ motifs are nearly identical in the absence or presence of $\mathrm{Ca}(\mathrm{II})$ (Figure 5), and atoms comprising the $\mathrm{His}_{6}$ motifs harbor similar B-factors for both the $\mathrm{Ca}(\mathrm{II})$-free and $\mathrm{Ca}(\mathrm{II})$ bound structures, indicating that these sites have comparable degrees of order. Thus, the $\mathrm{Ca}$ (II)-free structure does not provide information into how $\mathrm{Ca}$ (II) influences the metalbinding affinity at site 2 , and further investigations are required to probe this phenomenon.

\section{$\mathrm{Ni}(\mathrm{II})$ Coordination Causes Tetramerization in Solution}

To complement crystallographic analyses and further our understanding of how $\mathrm{Ni}$ (II) binding affects the biophysical properties of CP-Ser in solution, we performed solution studies to examine $\mathrm{Ni}(\mathrm{II})$ binding in the absence and presence of $\mathrm{Ca}$ (II) ions. We first employed analytical size-exclusion chromatography (SEC) to examine the effect of $\mathrm{Ni}$ (II) coordination on the quaternary structure of $\mathrm{CP}-\mathrm{Ser}$ and protein variants. The variants lack 
residues of site $1\left(\Delta \mathrm{His}_{3} \mathrm{Asp}\right)$, site $2\left(\Delta \mathrm{His}_{4}\right)$, or both sites 1 and $2(\Delta \Delta)$ or His residues of the S100A9 C-terminal tail (AAA, AHA, H103A, H104A, H105A) (Table S1).

All apo CP variants exhibit peak elution volumes of $\approx 11.4 \mathrm{~mL}$, consistent with the presence of a $\beta$ heterodimers (Figure S3). ${ }^{19}$ Following preincubation of CP-Ser, $\Delta \mathrm{His}_{3} \mathrm{Asp}$, and H104A with 5 equiv of $\mathrm{Ni}(\mathrm{II})$, the peak elution volumes shifted to $\approx 10.8 \mathrm{~mL}$. These new peaks exhibit comparable elution volumes to that of the $\mathrm{Ca}$ (II)-bound $\mathrm{a}_{2} \beta_{2}$ heterotetramer, indicating formation of $\mathrm{Ni}$ (II)-bound $\mathrm{a}_{2} \beta_{2}$ heterotetramers in the absence of $\mathrm{Ca}$ (II). In contrast, when $\Delta \mathrm{His}_{4}$ and $\Delta \Delta$ were preincubated with 5 equiv of $\mathrm{Ni}(\mathrm{II})$, the proteins exhibited the same peak elution volume as apo CP-Ser. Thus, these two variants did not form heterotetramers as a result of $\mathrm{Ni}$ (II) preincubation. We previously determined the stoichiometry of $\mathrm{Ni}$ (II) binding to CP-Ser and variants by SEC and observed that CP-Ser retained $\approx 2$ equiv of $\mathrm{Ni}(\mathrm{II})$ and that $\Delta \mathrm{His}_{3} \mathrm{Asp}$ and $\Delta \mathrm{His}_{4}$ retained $\approx 1$ equiv of $\mathrm{Ni}(\mathrm{II})$ over the elution protocol. ${ }^{17}$ These data indicate that $\mathrm{Ni}(\mathrm{II})$ binding at site 2 , and not at site 1 , results in tetramerization. This observation is consistent with prior studies that show that coordination of $\mathrm{Mn}$ (II) or $\mathrm{Fe}$ (II) to the $\mathrm{His}_{6}$ site of CP-Ser results in the formation of a $\mathrm{Ca}$ (II)-free heterotetramer. ${ }^{28}$ Lastly, whereas the AHA, H103A, and H105A variants exhibit comparable elution volume peak shifts with $\mathrm{Ni}(\mathrm{II})$ to CP-Ser, the AAA variant appears to have perturbed tetramerization because its chromatogram displays a shoulder. Similar behavior was observed for $\mathrm{Mn}$ (II) binding to the tail variants, where the presence of the His residues in the S100A9 C-terminal tail are important for complete transformation to the heterotetrameric species. ${ }^{11}$

\section{$\mathrm{Ni}(\mathrm{II})$ Coordination Increases the Thermal Stability of CP}

On the basis of our prior studies of Mn(II) and Zn(II) chelation to CP-Ser, ${ }^{9,19}$ we expected that $\mathrm{Ni}$ (II) binding enhances the thermal stability of the protein. We employed circular dichroism (CD) spectroscopy to monitor the thermal denaturation of CP-Ser in the presence of $\mathrm{Ni}$ (II) and both $\mathrm{Ni}$ (II) and $\mathrm{Ca}$ (II) (Figure $\mathrm{S} 4$ ). In the absence of $\mathrm{Ca}$ (II), $\mathrm{Ni}$ (II) binding increases the melting temperature $\left(\mathrm{T}_{\mathrm{m}}\right)$ of $\mathrm{CP}$-Ser from $\approx 65{ }^{\circ} \mathrm{C}$ to $\approx 80{ }^{\circ} \mathrm{C}$. In the presence of both $\mathrm{Ni}(\mathrm{II})$ and $\mathrm{Ca}(\mathrm{II})$, negligible protein unfolding was observed until $>95{ }^{\circ} \mathrm{C}$. These trends are consistent with results from prior thermal denaturation studies of $\mathrm{Zn}$ (II) and $\mathrm{Mn}$ (II) coordination. ${ }^{9,19}$

\section{$\mathrm{Ca}$ (II) Ions Enhance the Ni(II) Affinity of CP}

Our prior studies indicated that $\mathrm{Ca}(\mathrm{II})$ enhances the ability of $\mathrm{CP}$ to deplete $\mathrm{Ni}$ from bacterial growth media. ${ }^{14}$ We therefore reasoned that the affinity of $\mathrm{CP}$ for $\mathrm{Ni}$ (II) depends on $\mathrm{Ca}(\mathrm{II})$ coordination, as observed for other transition metals. ${ }^{9,14,19}$ We conducted $\mathrm{Ni}(\mathrm{II})$ competition experiments employing the $\mathrm{Ca}(\mathrm{II})$-insensitive metal sensor Zinpyr-1 (ZP1), which displays fluorescence quenching as a result of $\mathrm{Ni}(\mathrm{II})$ complexation (Figure S5). ${ }^{33}$ Although we did not ascertain an apparent dissociation constant value of $\mathrm{ZP} 1$ for $\mathrm{Ni}(\mathrm{II})$ and thus quantitative assessment of $\mathrm{Ni}$ (II) affinities for CP-Ser, this study indicated that $\mathrm{Ca}$ (II) ions enhance the $\mathrm{Ni}$ (II) affinity of CP-Ser (Figure S6). When Ni(II) was added to equimolar mixtures of ZP1 and $\mathrm{CP}-\mathrm{Ser}$ in the absence and presence of excess $\mathrm{Ca}(\mathrm{II})$ ions, the fluorescence from $\mathrm{ZP1}$ indicated that most of the added $\mathrm{Ni}(\mathrm{II})$ is bound to CP-Ser under both conditions, and that a larger fraction of total $\mathrm{Ni}(\mathrm{II})$ is bound to $\mathrm{CP}-\mathrm{Ser}$ in the presence of $\mathrm{Ca}(\mathrm{II})$. 


\section{$\mathrm{Ca}$ (II) Coordination Results in Slower Exchange of $\mathrm{Zn}$ (II) for $\mathrm{Ni}(\mathrm{II})$ at the $\mathrm{His}_{6}$ Site}

We previously observed that the presence of $\mathrm{Ca}$ (II) caused the substitution for transition metals (e.g. $\mathrm{Mn}(\mathrm{II}), \mathrm{Fe}(\mathrm{II}), \mathrm{Zn}(\mathrm{II})$ ) at the His 6 site to occur relatively slowly. ${ }^{14}$ To extend this work to $\mathrm{Ni}(\mathrm{II})$, we conducted a metal-substitution assay where we monitored the exchange of $\mathrm{Ni}(\mathrm{II})$ and $\mathrm{Zn}$ (II) at site 2 in the absence and presence of $\mathrm{Ca}(\mathrm{II})$ over $72 \mathrm{~h}$ (Figure 6). We pre-incubated B- $\Delta \mathrm{His}_{3} \mathrm{Asp}$, a biotinylated $\Delta \mathrm{His}_{3} \mathrm{Asp}$ variant (Table S1), ${ }^{17}$ with 1.0 equiv of either $\mathrm{Ni}$ (II) or $\mathrm{Zn}$ (II) and then added 1.0 equiv of the other metal ion. We then performed pull-down with streptavidin resin at varying time points and quantified the metal content in the resulting supernatant by inductively coupled plasma-mass spectrometry (ICP-MS). At the end of each time course, a higher concentration of $\mathrm{Zn}(\mathrm{II})$ remained in the supernatant, suggesting that $\mathrm{B}-\Delta \mathrm{His}_{3} \mathrm{Asp}$ removed during the pull-down step was predominately the $\mathrm{Ni}$ (II)-bound species. When $\mathrm{Ni}$ (II) was added first, $\mathrm{Zn}$ (II) displaced $\approx 30 \%$ of the $\mathrm{Ni}$ (II) over the incubation period (Figure 6A). When $\mathrm{Zn}$ (II) was added first, Ni(II) displaced $\approx 70 \%$ of the $\mathrm{Zn}$ (II) (Figure 6B). Thus, site 2 has a thermodynamic preference for $\mathrm{Ni}$ (II) over $\mathrm{Zn}$ (II) in the presence and absence of $\mathrm{Ca}(\mathrm{II})$, and the exchange between these two metal ions occurs more slowly in the presence of $\mathrm{Ca}(\mathrm{II})$.

\section{The His ${ }_{3}$ Asp Site Selects for Zn(II) Over Ni(II)}

Since the discovery that site 2 is a biologically unprecedented $\mathrm{His}_{6}$ site that sequesters $\mathrm{Mn}$ (II) and other metal ions, many studies have focused on delineating its biophysical and functional properties, and less emphasis has been placed on characterizing the $\mathrm{His}_{3} \mathrm{Asp}$ site. ${ }^{10-12,14-17,20}$ Nevertheless, investigations of CP-Ser ${ }^{20}$ as well as the host-defense proteins S100A $7^{34}$ and S100A $12^{35}$ have demonstrated that $\mathrm{His}_{3} \mathrm{Asp}$ sites sequester $\mathrm{Zn}(\mathrm{II})$. Moreover, studies of metal depletion from microbial growth media indicate that $\mathrm{His}_{3} \mathrm{Asp}$ sites select for $\mathrm{Zn}$ (II) over other metals, including $\mathrm{Ni}(\mathrm{II}) .{ }^{14,34,35}$ We therefore sought to examine metal exchange at the $\mathrm{His}_{3}$ Asp site using the pull-down assay described above. Efforts to purify a biotinylated $\mathrm{His}_{4}$ variant resulted in poor yields because the protein routinely precipitated, and we were unable to readily obtain sufficient quantities of this protein for the assay. We thus optimized a spin-filtration assay to examine metal substitution at the $\mathrm{His}_{3} \mathrm{Asp}$ site (Supporting Discussion). Under conditions of excess Ca(II), we pre-loaded $10 \mu \mathrm{M} \mathrm{CP}$-Ser with 2.0 equiv of $\mathrm{Ni}$ (II) and added 1.0 equiv of $\mathrm{Zn}$ (II) to the solution (75 mM HEPES, 100 $\mathrm{mM} \mathrm{NaCl}, \mathrm{pH} 7.4,2 \mathrm{mM} \mathrm{Ca}(\mathrm{II})$ ). Following incubation (up to $120 \mathrm{~min}$ ), the bound and unbound fractions were separated via spin filtration (10-kDa MWCO membrane), and the filtrate (unbound fraction) was analyzed by ICP-MS. Because site 2 has a thermodynamic preference for $\mathrm{Ni}$ (II) over $\mathrm{Zn}$ (II) (Figure 6), we reasoned that any unbound $\mathrm{Ni}$ (II) that is detected after $\mathrm{Zn}$ (II) addition would originate from the His ${ }_{3} \mathrm{Asp}$ site. ICP-MS analysis of samples taken at varying time points after $\mathrm{Zn}$ (II) addition revealed that the filtrate contained $\approx 2 \mu \mathrm{M} \mathrm{Zn(II)} \mathrm{and} \approx 7 \mu \mathrm{M} \mathrm{Ni(II)} \mathrm{following} 10 \mathrm{~min}$, which is the earliest time point that could be reliably analyzed by this method (Figure 7A). Over the course of $120 \mathrm{~min}$, the concentrations of $\mathrm{Zn}(\mathrm{II})$ and $\mathrm{Ni}(\mathrm{II})$ in the filtrate further decreased and increased, respectively, indicating that $\mathrm{Ni}(\mathrm{II})$ had been displaced from the $\mathrm{His}_{3} \mathrm{Asp}$ site by $\mathrm{Zn}$ (II). Moreover, a control performed with the $\Delta \mathrm{His}_{3} \mathrm{Asp}$ variant showed that $\mathrm{Ni}(\mathrm{II})$ remains bound to the $\mathrm{His}_{6}$ site under the assay conditions (Figure 7B). We also conducted this experiment in the absence of added $\mathrm{Ca}(\mathrm{II})$, and we observed similar metal substitution at site 1 of CP-Ser in the absence or presence of $\mathrm{Ca}$ (II) (Figure S7). Overall, these results demonstrate that the 
$\mathrm{His}_{3}$ Asp site has a thermodynamic preference for $\mathrm{Zn}$ (II) over $\mathrm{Ni}$ (II) and exhibits markedly more rapid metal exchange kinetics than the $\mathrm{His}_{6}$ site.

\section{Discussion}

In this work, we pursued X-ray protein crystallography and solution experiments to evaluate $\mathrm{Ni}(\mathrm{II})$ binding by $\mathrm{CP}-\mathrm{Ser}$ under conditions of low and high $\mathrm{Ca}(\mathrm{II})$ concentrations. This initiative was motivated by our previous report that CP-Ser binds $\mathrm{Ni}(\mathrm{II})$ at the $\mathrm{His}_{3} \mathrm{Asp}$ and $\mathrm{His}_{6}$ sites, and sequesters this metal nutrient from Staphylococcus aureus and Klebsiella pneumonaie, two bacterial pathogens that can colonize the urinary tract and employ the $\mathrm{Ni}$ enzyme urease during urinary tract infections. ${ }^{17}$ It also addresses the fundamental and unresolved question of how $\mathrm{Ca}$ (II) binding affects the structure and function of this remarkable host-defense protein. In particular, structural comparisons of the $\mathrm{Ni}$ (II)-bound $\mathrm{CP}-\mathrm{Ser}$ structure and our previously reported $\mathrm{Ni}$ (II)- and $\mathrm{Ca}$ (II)-bound structure reveal conformational changes associated with $\mathrm{Ca}$ (II) binding to the EF-hand domains and provide insight into how $\mathrm{Ca}$ (II) ions influence transition-metal coordination by $\mathrm{CP}$. This study also examines the metal-exchange properties of the $\mathrm{His}_{3} \mathrm{Asp}$ site of $\mathrm{CP}$, which has received less attention than the $\mathrm{His}_{6}$ site to date.

We first employed EDX spectroscopy to discern the metal content of CP-Ser crystals that we subsequently examined by X-ray diffraction. This synchrotron technique allows highresolution detection of K-edge energy emission of metals such as $\mathrm{Ca}, \mathrm{Mn}, \mathrm{Fe}, \mathrm{Ni}$, and $\mathrm{Zn} .{ }^{32}$ Unlike traditional methods for elemental analysis such as ICP-MS and atomic absorption/ emission spectroscopy, EDX line scans can be collected on crystalline samples as small as $50 \mu \mathrm{m}$ in length and can be obtained in tandem with X-ray diffraction experiments. Employing EDX spectroscopy, in combination with anomalous scattering, was helpful in this crystallographic work because CP-Ser has the capacity to coordinate a number of different metal ions. The technique confirmed that negligible $\mathrm{Ca}$ was present in the $\mathrm{Ca}$ (II)free crystal and, along with X-ray anomalous data, contributed to our unambiguous assignment of $\mathrm{Ni}(\mathrm{II})$ ions at the transition-metal-binding sites.

From the standpoint of biological $\mathrm{Ni}(\mathrm{II})$ sites, $\mathrm{CP}-\mathrm{Ser}$ is unusual because it can exhibit three different $\mathrm{Ni}(\mathrm{II})$ coordination motifs. Site 1 ( $\mathrm{His}_{3} \mathrm{Asp}$ ) exhibits one of two coordination modes depending on the presence of $\mathrm{Ca}$ (II): (i) a pseudooctahedral $\mathrm{Ni}$ (II) site composed of three nitrogen and three oxygen donors when $\mathrm{Ca}$ (II) is absent, and (ii) a tetrahedral $\mathrm{Ni}$ (II) site composed of three nitrogen donors and one oxygen ligand when $\mathrm{Ca}(\mathrm{II})$ is bound. Analysis of Ni(II)-chelating proteins in the Protein Data Bank (PDB) ${ }^{36}$ using the MESPEUS online database ${ }^{37}$ reveals only one other protein with a metal-binding site that is comparable to the six-coordinate $\mathrm{Ni}(\mathrm{II})$ center at site 1 (Table S8). The transcriptional regulator TM1602 of Thermotoga maritima has a $\mathrm{His}_{3}$ Glu motif where the bidentate Glu residue and a water molecule complete the $\mathrm{Ni}$ (II) coordination sphere. ${ }^{38}$ Moreover, to the best of our knowledge, no other four-coordinate $\mathrm{Ni}$ (II) site with three His residues and a carboxylate ligand is deposited in the PDB (Table S8). Site 2 is the hexahistidine site, and this $\mathrm{Ni}(\mathrm{II})$ motif has previously only been identified for His-tagged or engineered proteins. ${ }^{39-41}$ Nevertheless, in small-molecule complexes, mononuclear hexaimidazole Ni(II) centers have been structurally 
characterized, ${ }^{42,43}$ and the $\mathrm{Ni}(\mathrm{II})-\mathrm{His}_{6}$ sites of $\mathrm{CP}$ observed in the absence and presence of bound $\mathrm{Ca}(\mathrm{II})$ ions exhibit metal-ligand bond lengths comparable to these complexes.

The Ca(II)-induced conformational changes that occur at the His ${ }_{3}$ Asp motif and the S100A9 EF-hand domains adjacent to site 1 shows a new facet of how transition-metal binding is modulated at site 1 , at least in the case of a bound $\mathrm{Ni}(\mathrm{II})$ ion. At present, there is a paucity of information about the geometric and electronic structures of $\mathrm{M}(\mathrm{II})-\mathrm{His}_{3} \mathrm{Asp}$ in $\mathrm{CP}$, and reported studies are limited to $\mathrm{Fe}(\mathrm{II})$ and $\mathrm{Co}(\mathrm{II}) .{ }^{15,19}$ Comparable optical absorption transitions, suggesting a 4- or 5-coordinate geometry, are observed for $\mathrm{Co}$ (II) bound to the $\mathrm{His}_{3}$ Asp site in the absence and presence of $\mathrm{Ca}(\mathrm{II}) .{ }^{19}$ Subsequent near-infrared (NIR) magnetic circular dichroism (MCD) spectroscopic studies of Fe(II)-bound CP-Ser revealed a five-coordinate $\mathrm{Fe}(\mathrm{II})$ signal associated with site 1 in both the absence and presence of $\mathrm{Ca}$ (II) ions. ${ }^{15}$ Although the coordination number of the $\mathrm{Fe}$ (II) atom did not change, the presence of $\mathrm{Ca}(\mathrm{II})$ ions affected the ligand field of site 1 . Thus, whether the change of coordination number of $\mathrm{Ni}(\mathrm{II})$ bound to site 1 that occurs with $\mathrm{Ca}(\mathrm{II})$ binding is specific to this metal or can be generalized to others such as $\mathrm{Zn}$ (II) remains to be determined. Moreover, the exclusion of a solvent-derived ligand at site 1 in the presence of $\mathrm{Ca}(\mathrm{II})$ is reminiscent of our prior work on the His 6 site, which supports a model in which the S100A9 C-terminal tail precludes access of water molecules to the metal center and thereby contributes to the metal-sequestering function of CP. ${ }^{12,15}$

Structural comparisons of the $\mathrm{Ni}(\mathrm{II})$-bound $\mathrm{His}_{6}$ motif in the absence and presence of $\mathrm{Ca}(\mathrm{II})$ demonstrate that $\mathrm{Ca}$ (II) binding at the EF-hand domains has negligible effect on the primary coordination sphere of site 2 . These results are congruous with prior spectroscopic studies on $\mathrm{Mn}$ (II) and $\mathrm{Fe}$ (II) coordination at this site. ${ }^{12,15}$ Together, these data indicate that the enhanced affinities for transition metal ions observed at this $\mathrm{His}_{6}$ site for the $\mathrm{Ca}$ (II)-bound heterotetramer cannot be explained by changes in the primary sphere or electronic structure at this site. We expect that further investigations of allostery and $\mathrm{Ca}(\mathrm{II})$-induced tetramerization will inform how $\mathrm{Ca}(\mathrm{II})$ coordination enhances the transition-metal affinities of this site.

Deciphering metal selectivity and exchange at sites 1 and 2 also informs the current model for the metal-withholding function of CP. The present work provides further evidence for relatively slow metal exchange at the $\mathrm{His}_{6}$ site, and supports the notion that presence of $\mathrm{Ca}(\mathrm{II})$ ions reduces the metal exchange rate at this site to some degree. These observations further substantiate a model of "functional versatility" where the His ${ }_{6}$ site binds and entraps the metal ion it encounters first. In contrast, the current investigation of metal exchange at the $\mathrm{His}_{3} \mathrm{Asp}$ site indicates that it has a thermodynamic preference for $\mathrm{Zn}$ (II) over $\mathrm{Ni}$ (II) and displays relatively rapid substitution of $\mathrm{Zn}$ (II) for $\mathrm{Ni}$ (II) in both the absence and presence of $\mathrm{Ca}$ (II). The His ${ }_{3}$ Asp site has been described as $\mathrm{Zn}$ (II) selective in prior work, and $\mathrm{Zn}$ (II) sequestration by site 1 of $\mathrm{CP}$ has been shown to inhibit the growth of Lactobacillus plantarum and Candida albicans. ${ }^{20}$ The current data are consistent with this concept. Nevertheless, a recent study indicates that $\mathrm{CP}$ sequesters $\mathrm{Cu}$ (II) from $C$. albicans and that both sites 1 and 2 bind $\mathrm{Cu}(\mathrm{II})$ with high affinity. ${ }^{18}$ Whether the His ${ }_{3}$ Asp site has thermodynamic preference for $\mathrm{Zn}$ (II) or $\mathrm{Cu}$ (II) is currently unknown and an avenue for future work. 
In closing, $\mathrm{Ca}$ (II)-dependent properties of $\mathrm{S} 100$ proteins have been studied for several decades, ${ }^{24,44}$ and evidence for allosteric communication between the Ca(II)-binding EFhand domains and transition metal sites has also been reported for S100A12 and S100B. $35,45-47$ Although evidence for $\mathrm{Ca}(\mathrm{II})$ ions modulating the antimicrobial properties of $\mathrm{CP}$ emerged almost thirty years ago, ${ }^{2}$ only in the past decade have we learned that allosteric communication between the EF-hand domains and transition metal sites contributes to metal-sequestering ability of $\mathrm{CP} .{ }^{9,14,19}$ Expanding upon these recent studies, this work on $\mathrm{Ni}(\mathrm{II})$-bound $\mathrm{CP}-\mathrm{Ser}$ provides a structural snapshot of a $\mathrm{Ca}(\mathrm{II})$-free $\mathrm{CP}$ species and motivation for future studies that further address how $\mathrm{Ca}$ (II) binding modulates its structural and functional properties.

\section{Supplementary Material}

Refer to Web version on PubMed Central for supplementary material.

\section{Acknowledgments}

We acknowledge the the NSF (CHE-1352132 to E.M.N.), the NIH (R01GM126376 and R01GM118695 to E.M.N., R01GM069857 to C.L.D., F32-GM099257 to S.E.J.B.), the MIT Center for Environmental Health Sciences (NIH Grant P30-ES002109), the MIT Center for Environmental Health Sciences Theron Randolph Gift (E.M.N.), and the National Science Foundation Graduate Research Fellowship Program (T.G.N. and E.M.Z.) for providing financial support. C.L.D. is a Howard Hughes Medical Investigator. This work is based upon research conducted at the Northeastern Collaborative Access Team beamlines, which are funded by the National Institute of General Medical Sciences from the National Institutes of Health (P41 GM103403). The Pilatus 6M detector on beamline 24-ID-C is funded by a NIH-ORIP HEI grant (S10 RR029205). This research used resources of the Advanced Photon Source, a U.S. Department of Energy (DOE) Office of Science User Facility operated for the DOE Office of Science by Argonne National Laboratory under Contract No. DE-AC02-06CH11357. The Biophysical Instrumentation Facility for the Study of Complex Macromolecular Systems is supported by NSF grant 0070319. The ICP-MS instrument is housed in the MIT Center for Environmental Health Sciences Bioanalytical Core, which is supported by NIH grant P30-ES002109. We also thank Dr. K. Rajashankar for assistance with EDX data analysis, and Dr. E. C. Wittenborn and Ms. T. A. J. Grell for assistance with X-ray diffraction data collection and analysis.

\section{References}

1. Sohnle PG, Collins-Lech C, Wiessner JH. The zinc-reversible antimicrobial activity of neutrophil lysates and abscess fluid supernatants. J Infect Dis. 1991; 164:137-142. [PubMed: 2056200]

2. Sohnle PG, Collinslech C, Wiessner JH. Antimicrobial activity of an abundant calciumbinding protein in the cytoplasm of human neutrophils. J Infect Dis. 1991; 163:187-192. [PubMed: 1984467]

3. Johne B, Fagerhol MK, Lyberg T, Prydz H, Brandtzaeg P, Naess-Andresen CF, Dale I. Functional and clinical aspects of the myelomonocyte protein calprotectin. J Clin Pathol: Mol Pathol. 1997; 50:113-123.

4. Corbin BD, Seeley EH, Raab A, Feldmann J, Miller MR, Torres VJ, Anderson KL, Dattilo BM, Dunman PM, Gerads R, Caprioli RM, Nacken W, Chazin WJ, Skaar EP. Metal chelation and inhibition of bacterial growth in tissue abscesses. Science. 2008; 319:962-965. [PubMed: 18276893]

5. Hood MI, Skaar EP. Nutritional immunity: transition metals at the pathogen-host interface. Nat Rev Microbiol. 2012; 10:525-537. [PubMed: 22796883]

6. Clohessy PA, Golden BE. Calprotectin-mediated zinc chelation as a biostatic mechanism in host defence. Scand J Immunol. 1995; 42:551-556. [PubMed: 7481561]

7. Loomans HJ, Hahn BL, Li QQ, Phadnis SH, Sohnle PG. Histidine-based zinc-binding sequences and the antimicrobial activity of calprotectin. J Infect Dis. 1998; 177:812-814. [PubMed: 9498472]

8. Kehl-Fie TE, Chitayat S, Hood MI, Damo S, Restrepo N, Garcia C, Munro Kim A, Chazin Walter J, Skaar Eric P. Nutrient metal sequestration by calprotectin inhibits bacterial superoxide defense 
enhancing neutrophil killing of Staphylococcus aureus. Cell Host Microbe. 2011; 10:158-164. [PubMed: 21843872]

9. Hayden JA, Brophy MB, Cunden LS, Nolan EM. High-affinity manganese coordination by human calprotectin is calcium-dependent and requires the histidine-rich site formed at the dimer interface. $\mathrm{J}$ Am Chem Soc. 2013; 135:775-787. [PubMed: 23276281]

10. Damo SM, Kehl-Fie TE, Sugitani N, Holt ME, Rathi S, Murphy WJ, Zhang Y, Betz C, Hench L, Fritz G, Skaar EP, Chazin WJ. Molecular basis for manganese sequestration by calprotectin and roles in the innate immune response to invading bacterial pathogens. Proc Natl Acad Sci US A. 2013; 110:3841-3846.

11. Brophy MB, Nakashige TG, Gaillard A, Nolan EM. Contributions of the S100A9 C-terminal tail to high-affinity $\mathrm{Mn}(\mathrm{II})$ chelation by the host-defense protein human calprotectin. J Am Chem Soc. 2013; 135:17804-17817. [PubMed: 24245608]

12. Gagnon DM, Brophy MB, Bowman SEJ, Stich TA, Drennan CL, Britt RD, Nolan EM. Manganese binding properties of human calprotectin under conditions of high and low calcium: X-ray crystallographic and advanced electron paramagnetic resonance spectroscopic analysis. J Am Chem Soc. 2015; 137:3004-3016. [PubMed: 25597447]

13. Hadley RC, Gagnon DM, Brophy MB, Gu Y, Nakashige TG, Britt RD, Nolan EM. Biochemical and spectroscopic observation of $\mathrm{Mn}$ (II) sequestration from bacterial $\mathrm{Mn}$ (II) transport machinery by calprotectin. J Am Chem Soc. 2018; 140:110-113. [PubMed: 29211955]

14. Nakashige TG, Zhang B, Krebs C, Nolan EM. Human calprotectin is an iron-sequestering hostdefense protein. Nat Chem Biol. 2015; 11:765-771. [PubMed: 26302479]

15. Baker TM, Nakashige TG, Nolan EM, Neidig ML. Magnetic circular dichroism studies of iron(II) binding to human calprotectin. Chem Sci. 2017; 8:1369-1377. [PubMed: 28451278]

16. Nakashige TG, Nolan EM. Human calprotectin affects the redox speciation of iron. Metallomics. 2017; 9:1086-1095. [PubMed: 28561859]

17. Nakashige TG, Zygiel EM, Drennan CL, Nolan EM. Nickel sequestration by the host-defense protein human calprotectin. J Am Chem Soc. 2017; 139:8828-8836. [PubMed: 28573847]

18. Besold AN, Gilston BA, Radin JN, Ramsoomair C, Culbertson EM, Li CX, Cormack BP, Chazin WJ, Kehl-Fie TE, Culotta VC. The role of calprotectin in withholding zinc and copper from Candida albicans. Infect Immun. 2018; doi: 10.1120/IAI.00779-00717

19. Brophy MB, Hayden JA, Nolan EM. Calcium ion gradients modulate the zinc affinity and antibacterial activity of human calprotectin. J Am Chem Soc. 2012; 134:18089-18100. [PubMed: 23082970]

20. Nakashige TG, Stephan JR, Cunden LS, Brophy MB, Wommack AJ, Keegan BC, Shearer JM, Nolan EM. The hexahistidine motif of host-defense protein human calprotectin contributes to zinc withholding and its functional versatility. J Am Chem Soc. 2016; 138:12243-12251. [PubMed: 27541598]

21. Hunter MJ, Chazin WJ. High level expression and dimer characterization of the S100 EF-hand proteins, migration inhibitory factor-related proteins 8 and 14. J Biol Chem. 1998; 273:1242712435. [PubMed: 9575199]

22. Vogl T, Roth J, Sorg C, Hillenkamp F, Strupat K. Calcium-induced noncovalently linked tetramers of MRP8 and MRP14 detected by ultraviolet matrix-assisted laser desorption/ionization mass spectrometry. J Am Soc Mass Spectrom. 1999; 10:1124-1130. [PubMed: 10536818]

23. Korndörfer IP, Brueckner F, Skerra A. The crystal structure of the human (S100A8/S100A9) 2 heterotetramer, calprotectin, illustrates how conformational changes of interacting a-helices can determine specific association of two EF-hand proteins. J Mol Biol. 2007; 370:887-898. [PubMed: 17553524]

24. Santamaria-Kisiel L, Rintala-Dempsey AC, Shaw GS. Calcium-dependent and -independent interactions of the S100 protein family. Biochem J. 2006; 396:201-214. [PubMed: 16683912]

25. Gifford JL, Walsh MP, Vogel HJ. Structures and metal-ion-binding properties of the $\mathrm{Ca}^{2+}$-binding helix-loop-helix EF-hand motifs. Biochem J. 2007; 405:199-221. [PubMed: 17590154]

26. Strupat K, Rogniaux H, Van Dorsselaer A, Roth J, Vogl T. Calcium-induced noncovalently linked tetramers of MRP8 and MRP14 are confirmed by electrospray ionization-mass analysis. J Am Soc Mass Spectrom. 2000; 11:780-788. [PubMed: 10976885] 
27. Vogl T, Leukert N, Barczyk K, Strupat K, Roth J. Biophysical characterization of S100A8 and S100A9 in the absence and presence of bivalent cations. Biochim Biophys Acta. 2006; 1763:1298-1306. [PubMed: 17050004]

28. Stephan JR, Nolan EM. Calcium-induced tetramerization and zinc chelation shield human calprotectin from degradation by host and bacterial extracellular proteases. Chem Sci. 2016; 7:1962-1975. [PubMed: 26925211]

29. Irving I, Williams RJP. Irving Williams series. Nature. 1948; 162:746-747.

30. Grabarek Z. Structural Basis for Diversity of the EF-hand Calcium-binding Proteins. J Mol Biol. 2006; 359:509-525. [PubMed: 16678204]

31. Bertin EP. Introduction to X-Ray Spectrometric Analysis Springer US; Boston, MA: 1978 EnergyDispersive X-Ray Spectrometry; 231253

32. Bowman SEJ, Bridwell-Rabb J, Drennan CL. Metalloprotein crystallography: more than a structure. Acc Chem Res. 2016; 49:695-702. [PubMed: 26975689]

33. Walkup GK, Burdette SC, Lippard SJ, Tsien RY. A new cell-permeable fluorescent probe for $\mathrm{Zn}^{2+}$ J Am Chem Soc. 2000; 122:5644-5645.

34. Cunden LS, Brophy MB, Rodriguez GE, Flaxman HA, Nolan EM. Biochemical and functional evaluation of the intramolecular disulfide bonds in the zinc-chelating antimicrobial protein human S100A7 (psoriasin). Biochemistry. 2017; 56:5726-5738. [PubMed: 28976190]

35. Cunden LS, Gaillard A, Nolan EM. Calcium ions tune the zinc-sequestering properties and antimicrobial activity of human S100A12. Chem Sci. 2016; 7:1338-1348. [PubMed: 26913170]

36. Berman HM, Westbrook J, Feng Z, Gilliland G, Bhat TN, Weissig H, Shindyalov IN, Bourne PE. The Protein Data Bank. Nucl Acids Res. 2000; 28:235-242. [PubMed: 10592235]

37. Hsin K, Sheng Y, Harding MM, Taylor P, Walkinshaw MD. MESPEUS: a database of the geometry of metal sites in proteins. J Appl Crystallogr. 2008; 41:963-968.

38. Weekes D, Miller MD, Krishna SS, McMullan D, McPhillips TM, Acosta C, Canaves JM, Elsliger MA, Floyd R, Grzechnik SK, Jaroszewski L, Klock HE, Koesema E, Kovarik JS, Kreusch A, Morse AT, Quijano K, Spraggon G, van den Bedem H, Wolf G, Hodgson KO, Wooley J, Deacon AM, Godzik A, Lesley SA, Wilson IA. Crystal structure of a transcription regulator (TM1602) from Thermotoga maritima at 2.3 A resolution. Proteins: Struct, Funct Bioinf. 2007; 67:247-252.

39. Löw C, Neumann P, Tidow H, Weininger U, Haupt C, Friedrich-Epler B, Scholz C, Stubbs MT, Balbach J. Crystal structure determination and functional characterization of the metallochaperone SlyD from Thermus thermophilus. J Mol Biol. 2010; 398:375-390. [PubMed: 20230833]

40. Håkansson KO. The crystallographic structure of Na,K-ATPase N-domain at 2.6 A resolution. J Mol Biol. 2003; 332:1175-1182. [PubMed: 14499619]

41. Salgado EN, Lewis RA, Mossin S, Rheingold AL, Tezcan FA. Control of protein oligomerization symmetry by metal coordination: $C_{2}$ and $C_{3}$ symmetrical assemblies through $\mathrm{Cu}^{\mathrm{II}}$ and $\mathrm{Ni}^{\mathrm{II}}$ coordination. Inorg Chem. 2009; 48:2726-2728. [PubMed: 19267481]

42. Santoro A, Mighell AD, Zocchi M, Reimann CW. The crystal and molecular structure of hexakis(imidazole)nickel(II) nitrate, $\left(\mathrm{C}_{3} \mathrm{H}_{4} \mathrm{~N}_{2}\right)_{6} \mathrm{Ni}\left(\mathrm{NO}_{3}\right)_{2}$. Acta Crystallogr Sect B: Struct Sci. $1969 ; 25: 842-847$.

43. Konopelski JP, Reimann CW, Hubbard CR, Mighell AD, Santoro A. Hexakis(imidazole)nickel(II) chloride tetrahydrate. Acta Crystallogr Sect B: Struct Sci. 1976; 32:2911-2913.

44. Donato R, Cannon BR, Sorci G, Riuzzi F, Hsu K, Weber DJ, Geczy CL. Functions of S100 proteins. Curr Mol Med. 2013; 13:24-57. [PubMed: 22834835]

45. Moroz OV, Burkitt W, Wittkowski H, He W, Ianoul A, Novitskaya V, Xie J, Polyakova O, Lednev IK, Shekhtman A, Derrick PJ, Bjoerk P, Foell D, Bronstein IB. Both $\mathrm{Ca}^{2+}$ and $\mathrm{Zn}^{2+}$ are essential for S100A12 protein oligomerization and function. BMC Biochem. 2009; 10:11. [PubMed: 19386136]

46. Baudier J, Glasser N, Gerard D. Ions binding to S100 proteins. I. Calcium- and zinc-binding properties of bovine brain $\mathrm{S} 100 \mathrm{aa}, \mathrm{S} 100 \mathrm{a}(\mathrm{a} \beta)$, and $\mathrm{S} 100 \mathrm{~b}(\beta \beta)$ protein: $\mathrm{Zn}^{2+}$ regulates $\mathrm{Ca}^{2+}$ binding on S100b protein. J Biol Chem. 1986; 261:8192-8203. [PubMed: 3722149]

47. Chaudhuri D, Horrocks WD, Amburgey JC, Weber DJ. Characterization of lanthanide ion binding to the EF-hand protein S100 $\beta$ by luminescence spectroscopy. Biochemistry. 1997; 36:9674-9680. [PubMed: 9245399] 

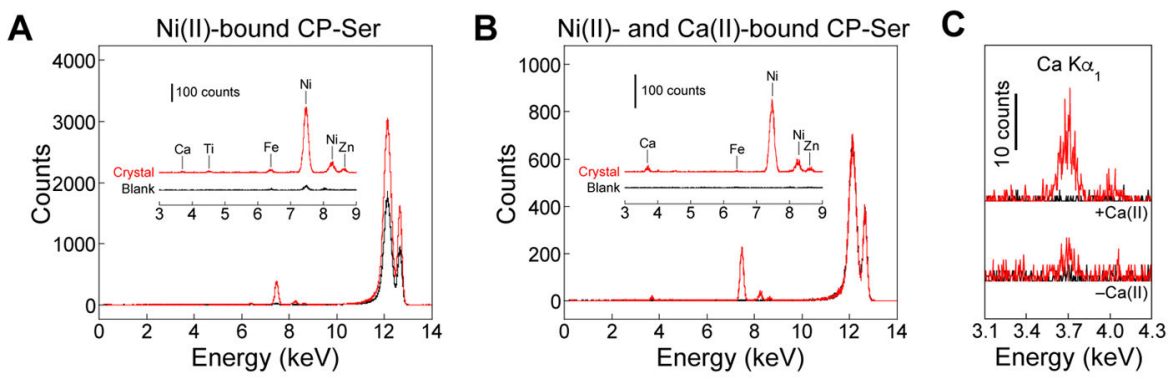

Figure 1.

EDX emission spectra of CP-Ser crystals. The metal content of each protein crystal was analyzed prior to X-ray diffraction data collection. (A) The Ni(II)-bound CP-Ser crystal contains Ni, Ca, and Zn as well as trace amounts of Ti and Fe. (B) The Ni(II)- and Ca(II)bound $\mathrm{CP}-\mathrm{Ser}$ crystal contains $\mathrm{Ni}$ and $\mathrm{Zn}$ as well as trace amounts of $\mathrm{Ca}$ and Fe. (C) Zoom on $\mathrm{Ca} \mathrm{Ka}_{1}$ region of both samples. Scans were obtained for the protein crystal (red line) and a blank sample (black line). Compton scatter is observed at the fixed incident energy at $0.9792 \AA(12,622 \mathrm{eV})$. Peak positions indicated on the plots correspond to element K-edge transitions: $\mathrm{Ca} \mathrm{Ka} a_{1}(3.69 \mathrm{keV}), \mathrm{Ti} \mathrm{Ka}_{1}(4.51 \mathrm{keV}), \mathrm{Fe} \mathrm{Ka}_{1}(6.40 \mathrm{keV}), \mathrm{Ni} \mathrm{Ka} \mathrm{Ka}_{1}(7.48 \mathrm{keV})$, $\mathrm{Ni} \mathrm{K} \beta_{1}(8.26 \mathrm{keV})$, and $\mathrm{Zn} \mathrm{Ka} a_{1}(8.64 \mathrm{keV})$. We note that the magnitude of counts are different between the $\mathrm{Ca}(\mathrm{II})$-free and $\mathrm{Ca}(\mathrm{II})$-bound analyses. The ratio of $\mathrm{Ca} / \mathrm{Ni}$ in the $\mathrm{Ni}(\mathrm{II})$ and $\mathrm{Ca}$ (II)-bound $\mathrm{CP}$-Ser is larger than the negligible ratio of $\mathrm{Ca} / \mathrm{Ni}$ in the $\mathrm{Ni}(\mathrm{II})$-bound $\mathrm{CP}$ Ser. These data are hard to quantify because the Ca signal in the Ca-free crystal is just above the noise. Although the data collection time for each sample and its corresponding blank were identical, the collection time and thickness of crystals varied between sample/blank pairs, accounting for the differences in count magnitude observed. 
A

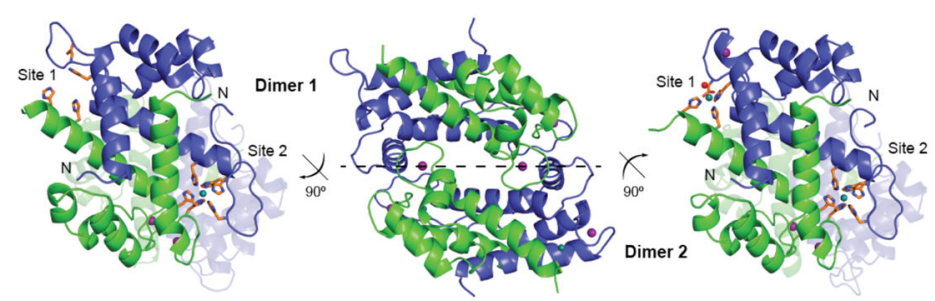

B
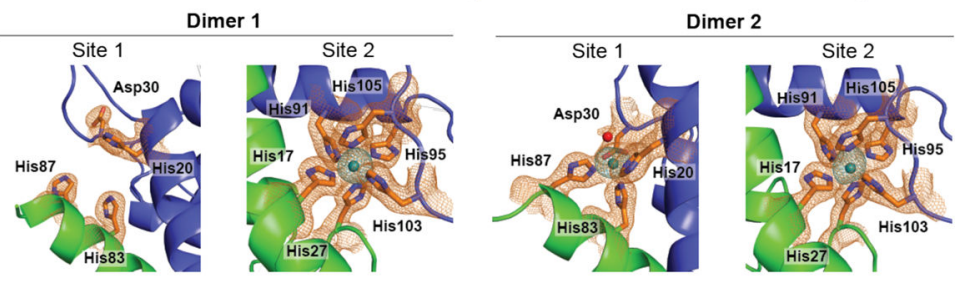

Figure 2.

$\mathrm{Ni}$ (II)-bound CP-Ser crystal structure. (A) CP-Ser forms an $a_{2} \beta_{2}$ heterotetramer (middle) in the presence of Ni(II). The dashed line represents the dimer-dimer interface. The two heterodimers (left and right) are shown. The transition-metal-binding sites and the N-termini are labeled. The S100A8 subunits of both dimers 1 and 2 bind two $\mathrm{Na}(\mathrm{I})$ ions at the noncanonical and canonical EF-hand domains. The S100A9 subunit of dimer 2 binds one $\mathrm{Na}$ (I) ion at the noncanonical EF-hand domain. (B) Two transition-metal-binding sites form at the S100A8/S100A9 interface. The sites of each heterodimer are shown. Dimer 1 binds one $\mathrm{Ni}(\mathrm{II})$ at site 2 , and dimer 2 binds two $\mathrm{Ni}$ (II) ions located at sites 1 and 2 . The metal occupancy is summarized in Table 1. S100A8 is green, S100A9 is blue, Ni(II) ions are teal spheres, $\mathrm{Na}(\mathrm{I})$ ions are purple spheres, and water molecules are red spheres. A $2 F_{O}-F_{C}$ composite omit electron density map (orange mesh) to 2.1 - $\AA$ resolution is contoured at $1 \sigma$ around the metal sites. A 2.3- $\AA$ resolution nickel anomalous difference map, calculated using data collected at a wavelength of $1.4831 \AA$, is contoured at $5 \sigma$ and shown in teal. 
A

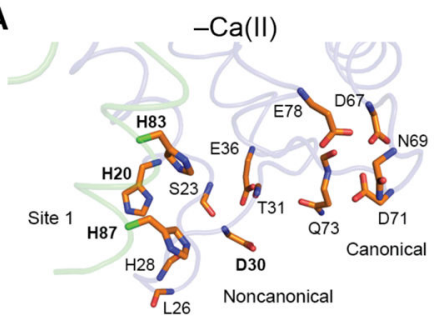

B

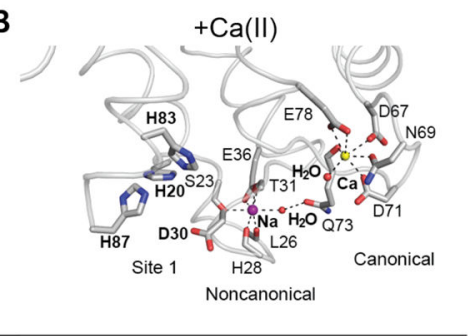

Dimer 1

C

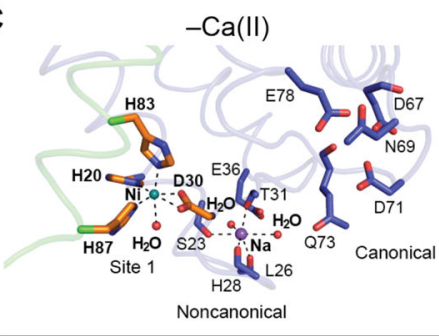

D

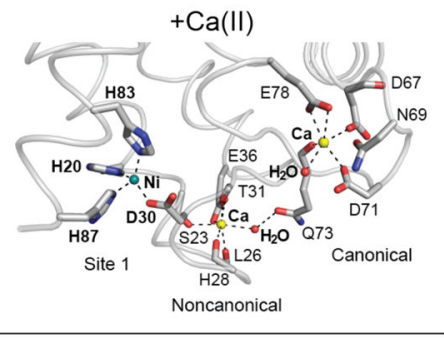

Dimer 2

Figure 3.

Calcium-induced conformational changes near site 1. In these structural alignments, the metal-binding ligands of the EF-hands are shown (Table S7). (A and B) In dimer 1, Ca(II) binding at the canonical EF-hand domain of S100A9 results in conformational changes in the non-canonical domain and allows for (A9)Asp30 to be positioned to form the His ${ }_{3}$ Asp motif. The loop of the non-canonical EF-hand domain exhibits a relatively large conformational change. (C and D) Coordination of $\mathrm{Ca}(\mathrm{II})$ ions at both EF-hand domains results in a change in coordination number at the $\mathrm{His}_{3} \mathrm{Asp}$ motif of dimer 2. In the $\mathrm{Ca}$ (II)free structure, two water molecules coordinate the $\mathrm{Na}(\mathrm{I})$ ion at the S100A9 non-canonical EF-hand domain, whereas a bidentate Glu36 and one water molecule (with a hydrogen bond interaction with Gln73) coordinate $\mathrm{Ca}$ (II) in the $\mathrm{Ca}$ (II)-bound form. The $\mathrm{Ca}$ (II)-free structures (A and C) are depicted in color, where S100A8 is green and S100A9 is blue. The $\mathrm{Ca}$ (II)-bound structures (B and D) are in gray. The residues of site 1 and the EF-hand domains are in orange $(-\mathrm{Ca}(\mathrm{II}))$ or gray $(+\mathrm{Ca}(\mathrm{II}))$. $\mathrm{Ni}(\mathrm{II})$ ions are teal spheres. $\mathrm{Na}(\mathrm{I})$ ions are purple spheres. $\mathrm{Ca}(\mathrm{II})$ ions are yellow spheres. Water molecules are red spheres. Metalligand and hydrogen bonds are shown as dashed lines. 

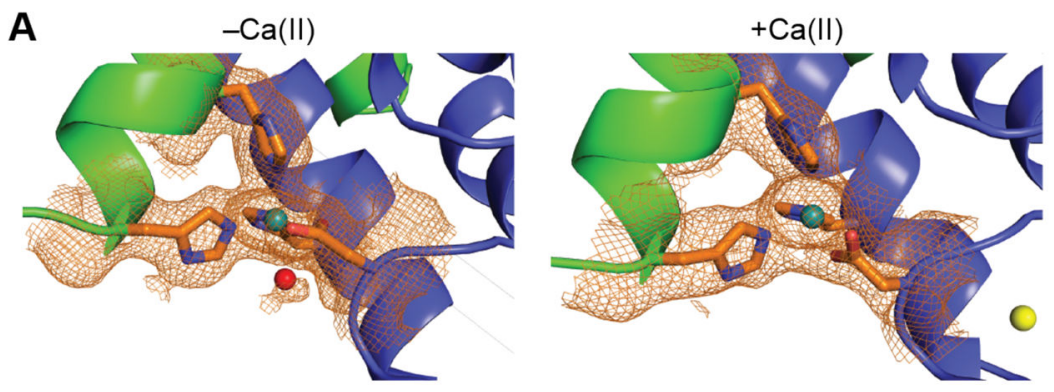

B
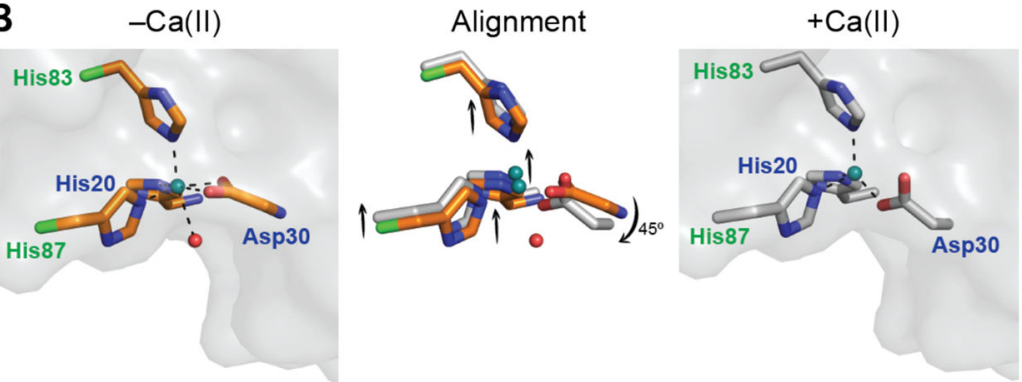

Figure 4.

Change in coordination number at the His ${ }_{3}$ Asp motif of dimer 2 with $\mathrm{Ca}$ (II) binding. (A) Electron density at site 1 of dimer 2 in the $\mathrm{Ca}$ (II)-free and $\mathrm{Ca}$ (II)-bound CP-Ser crystal structures. A $2 F O-F c$ composite omit electron density map (orange mesh) to $2.1-\AA$ (-Ca(II)) or $2.6-\AA(+\mathrm{Ca}(\mathrm{II}))$ resolution is contoured at $0.5 \sigma$ around the $\mathrm{His}_{3} \mathrm{Asp}$ motif. (B) The sixcoordinate $\mathrm{Ni}$ (II) site of the $\mathrm{Ca}$ (II)-free structure is shown in color (left), and the fourcoordinate $\mathrm{Ni}(\mathrm{II})$ site of the $\mathrm{Ca}$ (II)-bound structure is shown in gray (right). The metalbinding residues are depicted in orange $(-\mathrm{Ca}(\mathrm{II}))$ and gray $(+\mathrm{Ca}(\mathrm{II}))$. Space-filling models of the proteins are shown in gray. A structural alignment of all alpha carbons is depicted in the middle, and the conformational changes from $\mathrm{Ca}$ (II)-free to $\mathrm{Ca}$ (II)-bound are shown as arrows. S100A8 residues are labeled in green, and S100A9 residues are labeled in blue. $\mathrm{Ni}(\mathrm{II})$ ions are teal spheres. The water molecule is a red sphere. Metal-ligand bonds are shown as dashed lines. 


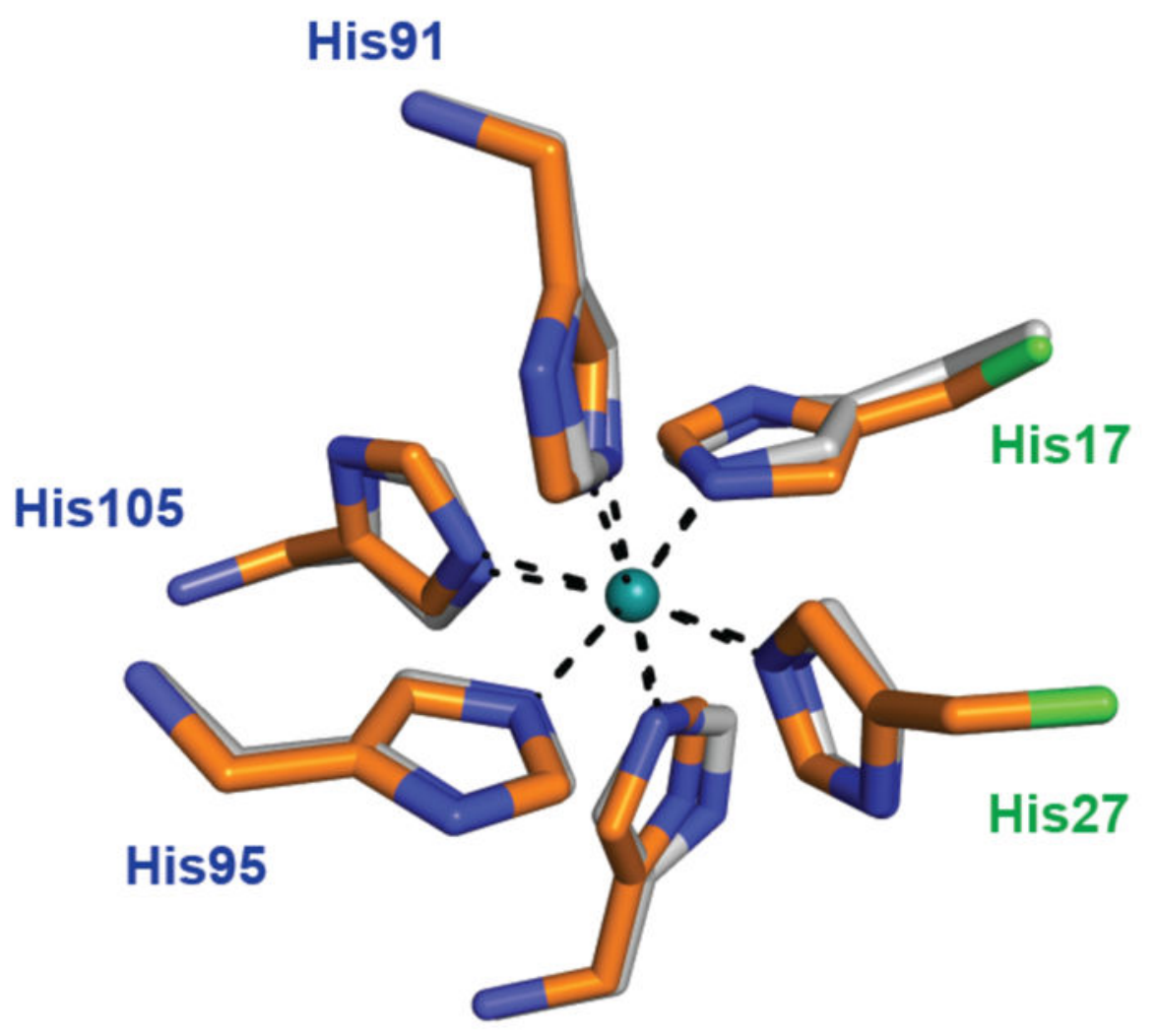

His103

Figure 5.

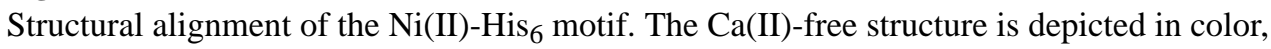
and the $\mathrm{Ca}(\mathrm{II})$-bound structure is in gray. S100A8 residues are labeled in green, and S100A9 residues are labeled in blue. The $\mathrm{Ni}(\mathrm{II})$ ion is depicted as a teal sphere. Models of site 2 of dimer 1 are shown. Further details of the structural alignment at site 2 are shown in Figure S2. 

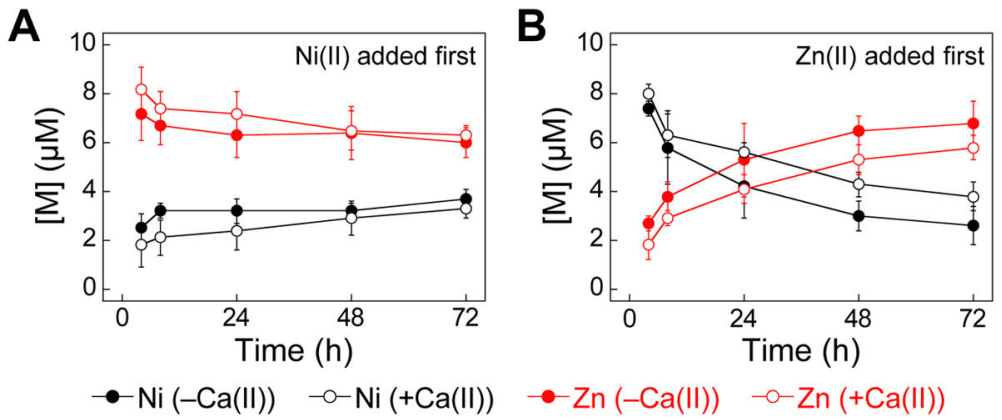

Figure 6.

Metal substitution of the $\mathrm{His}_{6}$ site is slowed in the presence of $\mathrm{Ca}(\mathrm{II})$. Metal content of supernatant of B- $\Delta \mathrm{His}_{3} \mathrm{Asp}(10 \mu \mathrm{M})$ incubated with $10 \mu \mathrm{M} \mathrm{Ni}$ (II) and $\mathrm{Zn}$ (II) in the absence and presence of $2 \mathrm{mM} \mathrm{Ca(II)} \mathrm{(room} \mathrm{temperature;} 75 \mathrm{mM}$ HEPES, $100 \mathrm{mM} \mathrm{NaCl}, \mathrm{pH} 7.0$ ) after treatment with streptavidin agarose resin. (A) $\mathrm{Zn}$ (II) was added to a pre-equilibrated solution of $\mathrm{Ni}$ (II) and $\mathrm{B}-\Delta \mathrm{His}_{3} \mathrm{Asp}$. (B) $\mathrm{Ni}$ (II) was added to a pre-equilibrated solution of $\mathrm{Zn}$ (II) and B- $\Delta \mathrm{His}_{3} \mathrm{Asp}$. The Ni (black) and $\mathrm{Zn}$ (red) concentrations were measured by ICPMS. Closed circles represent metal content without $\mathrm{Ca}(\mathrm{II})$, and open circles represent metal content with $\mathrm{Ca}(\mathrm{II})$. The mean and SDM are reported $(n=4)$. 

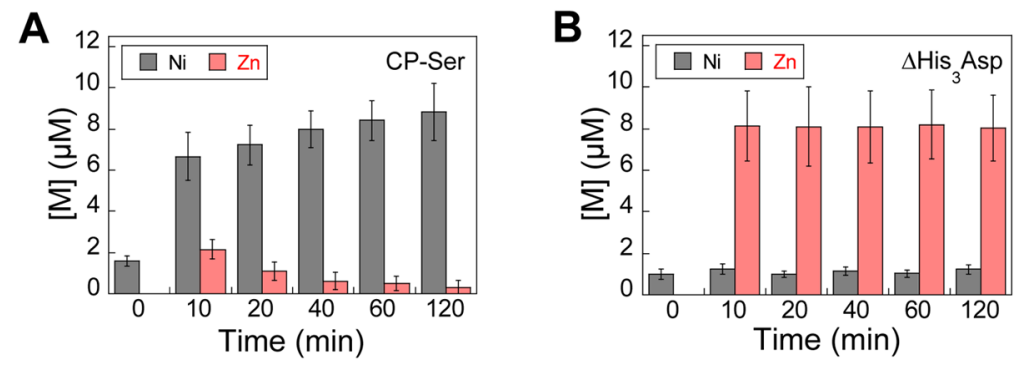

Figure 7.

$\mathrm{Zn}$ (II) rapidly displaces $\mathrm{Ni}$ (II) at the $\mathrm{His}_{3} \mathrm{Asp}$ site in the presence of $2 \mathrm{mM} \mathrm{Ca}$ (II). (A) Metal content of filtrate of CP-Ser $(10 \mu \mathrm{M})$ pre-incubated with $20 \mu \mathrm{M} \mathrm{Ni}$ (II) and supplemented with $10 \mu \mathrm{M} Z \mathrm{Zn}$ (II). (B) Metal content of filtrate of His ${ }_{3} \mathrm{Asp}(10 \mu \mathrm{M})$ pre-incubated with 10 $\mu \mathrm{M}$ Ni(II) and supplemented with $10 \mu \mathrm{M} \mathrm{Zn}$ (II). All solutions of protein and metal contained $2 \mathrm{mM} \mathrm{Ca}(\mathrm{II})$ and were prepared in $75 \mathrm{mM}$ HEPES, $100 \mathrm{mM} \mathrm{NaCl}, \mathrm{pH}$ 7.0. Protein was incubated for 1 hour with $\mathrm{Ni}(\mathrm{II})$ before $\mathrm{Zn}$ (II) addition. The $\mathrm{t}=0 \mathrm{~h}$ time point is the flow through before $\mathrm{Zn}$ (II) addition, and all subsequent times correspond to the time post- $\mathrm{Zn}$ (II) addition. The Ni (gray) and Zn (red) concentrations were measured by ICP-MS. The mean and SDM are reported $(n=3)$. Data obtained in the absence of $2 \mathrm{mM} \mathrm{Ca(II)}$ are presented in Figure S7. 

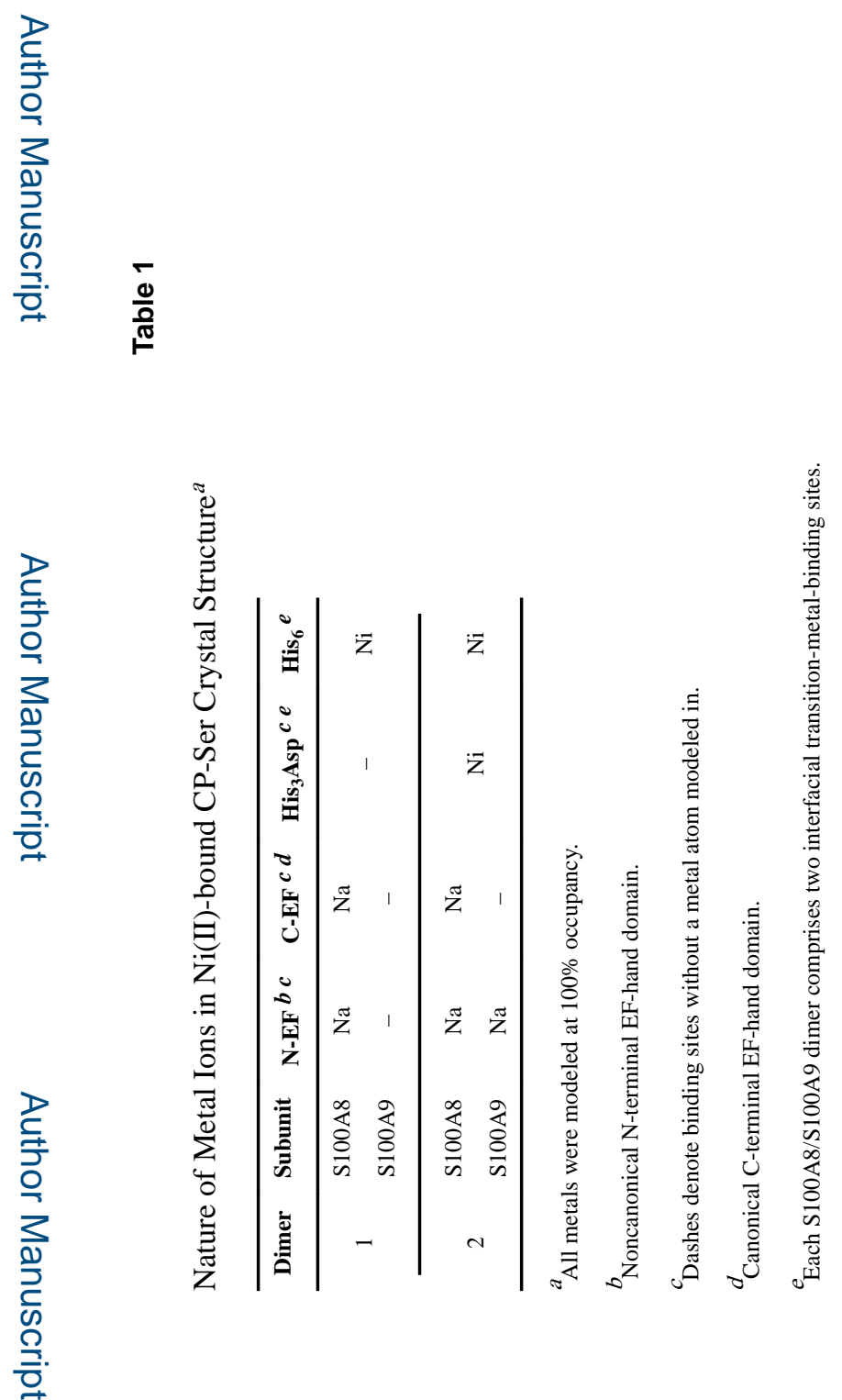

Biochemistry. Author manuscript; available in PMC 2018 July 17. 